\title{
Penerapan Hukum Progresif dalam Penegakan Hukum di tengah Krisis Demokrasi
}

\author{
Yanto Sufriadi \\ Fakultas Hukum Universitas Hazairin \\ Jl. Jenderal Ahmad Yani No. 1 Bengkulu \\ yanto_sufriadi@yahoo.co.id
}

\begin{abstract}
This research is focused on the impact of globalization within the justice, welfare, and democracy, as well as to the question about what kind of law that is possible to create the justice and the welfare in the middle of democracy crisis is and also the question about how to apply that in Indonesia's court. This study uses socio-legal approach which is mainly committing a quantitative method, based on the literature data. By using socio-legal approach, this study will conduct two kind approaches, which are social and normative juridical. This research makes claim that the globalization has finally made an impact to the happen of economy discriminatory and the widen case of poverty. Poverty will lead a bad impact to the democracy. In a situation of elitist legislation product, the settlement of law that is based on the legalpositivism tradition, it will give impact to the spread of discrimination and poverty. Because of it, in the middle of elitism legislation product, the progressive application of law can be considered as the alternative way to bring out the justice and the welfare for the people. The practice of Indonesia's court has shown its development to the law's progressive movement, nevertheless, the legal-positivism mainstream is still laid on several judges.
\end{abstract}

Keywords : Globalization, democracy, justice, progressive law.

\begin{abstract}
Abstrak
Penelitian ini difokuskan pada dampak globalisasi terhadap keadilan, kesejahteraan dan demokrasi serta konsep hukum yang bagaimanakah yang lebih memungkinkan untuk mewujudkan keadilan dan kesejahteraan rakyat di tengah krisis demokrasi dan bagaimanakah pelaksanaan dalam praktik pengadilan di Indonesia. Metode yang digunakan dalam studi ini adalah socio-legal approach yang bersifat kualitatif, berdasarkan data kepustakaan. Dengan pendekatan socio-legal approach, studi ini menggunakan dua pendekatan, yaitu pendekatan sosial dan pendekatan yuridis normatif. Penelitian ini menyimpulkan globalisasi telah mengakibatkan terjadinya kesenjangan (ketidakadilan) ekonomi dan meluasnya kemiskinan. Kemiskinan akan berdampak buruk terhadap demokrasi. Dalam situasi produk legislasi yang elitis, maka penerapan hukum yang didasarkan pada tradisi legal-positivism, akan semakin memperluas ketidakadilan dan kemiskinan. Karena, itu, di tengah situasi produk legislasi yang elitis, penerapan hukum secara progresif, merupakan cara alternatif yang lebih memungkinkan untuk mewujudkan keadilan dan kesejahteraan rakyat. Praktik pengadilan di Indonesia, menunjukkan mulai berkembangnya cara-cara penerapan hukum yang progresif, namun tradisi legal-positivism masih menjadi mainstream para hakim.
\end{abstract}

Kata Kunci : Globalisasi, demokrasi, keadilan, hukum progresif. 


\section{Pendahuluan}

Hubungan hukum, keadilan dan demokrasi menjadi urgen untuk kembali di diskusikan, terutama berkaitan dengan pengaruh dari globalisasi. Pada satu sisi, globalisasi diyakini sebagai pendorong gelombang demokrasi dunia. Huntington menyebutkan bahwa sekarang ini, tidak kurang 117 negara di dunia dari sekitar 191 negara telah melakukan pemilihan umum multipartai. Ini berarti bahwa sistem politik demokrasi telah dianut oleh sebahagian besar negara-negara di dunia. ${ }^{1}$ Ini membangkitkan optimisme terhadap globalisasi, karena dengan meluasnya demokrasi, hukum perundang-undangan yang merupakan produk politik tersebut, diharapkan akan lebih merupakan ekspresi kepentingan rakyat banyak dari pada kepentingan elit, sehingga akan lebih berkeadilan.

Pada sisi lain, ditengah optimisme yang demikian, juga muncul kekhawatiran yang sama besarnya. Struktur ekonomi global, mengalami banyak perubahan. Negara bangsa dalam konteks ini tidak lagi menjadi aktor tunggal dalam hukum, ekonomi, dan politik internasional. Peran negara banyak dipengaruhi oleh lembaga-lembaga internasional dan negara-negara kawasan. ${ }^{2}$

Lembaga-lembaga internasional, seperti WTO, IMF dan Bank Dunia, telah menjadi suatu kekuatan yang sangat berpengaruh di luar negara bangsa, bahkan dalam kasus tertentu, lembaga-lembaga ini mempunyai daya pemaksa yang sangat kuat dalam pembentukan hukum perundang-undangan untuk mendukung missi globalisasi ekonomi; terutama terhadap negara-negara yang mengalami krisis. ${ }^{3}$ Pertumbuhan perusahaan multinasional (MNCs). dalam beberapa dekade belakangan, juga telah menjadi aktor ekonomi politik internasional yang semakin penting, yang dalam kiprahnya banyak mempengaruhi kebijakan negara nasional, untuk melahirkan kebijakan yang menguntungkan kepentingannya. Situasi yang demikian, dapat berdampak buruk terhadap demokrasi, terutama berkaitan dengan pembentukan hukum yang dihasilkan dari proses legislasi, yang cenderung akan lebih berpihak pada kepentingan elit dari pada kepentingan rakyat banyak di negara tersebut, sehingga tujuan hukum untuk mewujudkan keadilan dan kesejahteraan rakyat banyak akan menjauh dari harapan.

\footnotetext{
${ }^{1}$ Jan Aart Scholte, Globalization : A Critical Introduction, St. Martin Press, New York, 2000, hlm. 263

${ }^{2}$ Kenich Ohmae, Hancurnya Negara Bangsa, Bangkitya Negara Kawasan dan Geliat Ekonomi Regional di Dunia Tak Terbatas, Qalam, Yogyakarta, 2002, hlm. 5

${ }^{3}$ Wiliam I. Robinson, Neoliberalisme : Elit Global dan Transisi Guatemala : sebuah Analisis Kritis Makrostruktural, dalam Wiliam I . Robinson, (Ed) Hantu Neoliberalisme, C-Books, Jakarta, 2003, hlm. 89
} 
Dalam situasi hukum perundang-undangan yang elitis demikian, maka apabila penerapan hukum perundang-undangan dilakukan dengan menggunakan konsep hukum sebagaimana yang dipahami dalam tradisi berpikir legal-positivism; yang memandang hukum hanya sebatas pada lingkaran peraturan perundang-undangan dan yang melakukan pemaknaan perundang-undangan secara formal-tekstual; dengan mengabaikan nilai-nilai sosial dalam masyarakat, maka yang akan terjadi adalah hukum yang mengabdi kepada kepentingan elit, bukan kepada kepentingan rakyat banyak, sehingga tujuan hukum untuk mewujudkan keadilan akan semakin jauh dari apa yang diharapkan.

Untuk itu, penerapan hukum memerlukan adanya konsep hukum lain, yang lebih memungkinkan pencapaian tujuan hukum untuk mewjudkan keadilan dan kesejahteraan rakyat banyak. Konsep hukum progresif, yang memaknai hukum untuk manusia dan masyarakat dan bukan untuk kepentingan dirinya sendiri, merupakan alternatif yang dapat dipergunakan dalam penerapan hukum, yang lebih memungkinkan untuk mewujudkan tujuan hukum yang demikian itu.

\section{Rumusan Masalah}

Pertama, bagaimanakah dampak globalisasi terhadap keadilan, kesejahteraan dan demokrasi? Kedua, konsep hukum yang bagaimanakah yang lebih memungkinkan untuk mewujudkan keadilan dan kesejahteraan rakyat di tengah krisis demokrasi dan bagaimanakah pelaksanaan dalam praktik pengadilan di Indonesia?

\section{Tujuan Penelitian}

Pertama, untuk menjelaskan bagaimana dampak globaliasi terhadap keadilan, kesejahteraan dan demokrasi serta bagaimana dampak dari krisis demokrasi terhadap hukum yang dihasilkan dari proses legislasi. Kedua, untuk menjelaskan penggunaan konsep hukum progresif sebagai cara alternatif yang dapat dipergunakan dalam penegakan hukum di tengah situasi krisis, dan bagaimana konsep tersebut telah diterapkan dalam praktik pengadilan di Indonesia. 


\section{Metode Penelitian}

Metode yang digunakan dalam studi ini adalah socio-legal approach yang bersifat kualitatif, berdasarkan data kepustakaan. Dengan pendekatan socio-legal approach, studi ini menggunakan dua pendekatan, yaitu pendekatan sosial dan pendekatan yuridis normatif. Pendekatan sosial dipergunakan untuk menganalisis situasi sosialekonomi dan sosial politik, guna menjelaskan nilai-nilai keadilan, kesejahteraan dan nilai demokrasi yang terwujud dalam masyarakat sebagai dampak globalisasi. Sedangkan pendekatan yuridis normatif dipergunakan untuk menganalisis norma peraturan perundang-undangan dan putusan hakim, dengan mengacu pada nilainilai kesejahteraan dan keadilan dalam masyarakat. Analisis yang dilakukan bersifat kualitatif; yang tidak menekankan pada kuantitas data; melainkan pada kualitasnya. Studi dilakukan menggunakan data kepustakaan, dengan menelusuri dokumen peraturan perundang-undangan, buku, jurnal hukum, hasil-hasil penelitian dan putusan pengadilan yang relevan untuk menjelaskan permasalahan dalam studi ini.

\section{Hasil Penelitian dan Pembahasan}

\section{Dampak Globalisasi terhadap Keadilan, Kesejahteraan dan Demokrasi}

Globalisasi ekonomi yang terjadi sekarang ini, sesungguhnya digerakkan oleh neoliberalisme, yakni suatu "isme" dengan misi khusus, yaitu mengurangi campur tangan negara dalam ekonomi untuk diganti dengan pasar. Artinya pasar ingin dijadikan satu-satunya cara atau sistem untuk mengatur perekonomian dan sekaligus satu-satunya tolok ukur untuk menilai keberhasilan semua kebijakan pemerintah. Sebagai implikasinya, masyarakat dan negara hanyalah instrumen yang diperlukan untuk menjamin terjadinya akumulasi kekayaan oleh anggota-anggota partikelir dalam masyarakat. Peran negara harus surut, digantikan oleh individu-individu swasta. ${ }^{4}$

Faham neoliberalisme ini, dalam pekembangannya telah memberikan pengaruh besar terhadap banyak negara di dunia, tidak terkecuali negara-negara yang selama ini menganut negara kesejahteraan (welfare staats). Di negara-negara berkembang,

\footnotetext{
${ }^{4}$ Lihat Deliarnov, Ekonomi Politik, Penerbit Erlangga, Jakarta, 2006, hlm. 164.
} 
agenda neoliberalisme mudah masuk karena pengaruh lembaga-lembaga keuangan internasional seperti International Monetery Found (IMF). Internastional Bank for Reconstruction and Development (IBRD), dan World Trade Organization (WTO).

IMF bertugas sebagai pengatur sistem keuangan dan sistem nilai tukar internasional. Selain itu juga dirancang untuk menolong negara-negara yang mengalami kesulitan dalam neraca pembayaran, dengan memberikan bantuan hutang luar negeri. Fungsi lainnya adalah menstabilkan ekonomi global. (IBRD) yang kemudian lebih dikenal dengan World Bank (Bank Dunia), umumnya menyediakan paket hutang untuk proyek-proyek dan program-program pembangunan infrastruktur, pendidikan, pemberantasan kemiskinan, menjaga lingkungan dan sejenisnya. ${ }^{5}$

Misi utama WTO adalah menghilangkan sekat-sekat perdagangan, dengan mengeluarkan peraturan-peraturan yang harus ditaati semua negara anggota yang ikut menandatangani perjanjian. Harapan yang ingin dicapai ialah mengatur jalannya perdagangan bebas dunia, baik perdagangan barang, jasa-jasa dan Hak Atas Kekayaan Intelektual (HAKI) dan investasi yang terkait dengan perdagangan.

Dalam kiprahnya menyokong neoliberalisme, IMF dan Bank Dunia, banyak melakukan 'penekanan' terhadap negara-negara yang 'ditolong'-nya, untuk melakukan kebijakan liberalisasi, deregulasi dan privatiasi, yang merupakan agenda politik neoliberal untuk membuka pasar nasional, dengan menyurutkan peran negara-negara yang 'ditolong' -nya dalam perekonomian. Misi IMF dan Bank Dunia ini memperlihatkan hasil yang luar biasa, yang ditandai oleh terbukanya pasar nasional di hampir seluruh negara di dunia. Sementara WTO, menopang neoliberalisme dengan mewadahi negara-negara untuk membentuk kesepakatankesepakatan dalam perdagangan internasional di antara negara-negara anggota, yang pada akhirnya ditujukan untuk menghapus segala bentuk hambatan dalam perdagangan internasional; baik hambatan tarif maupun hambatan non tarif.

Ketika sekat-sekat perdagangan antar negara sudah terbuka, berkat kebijakan deregulasi yang dilakukan oleh negara-negara anggota, perdagangan menjadi mendunia. Arus modal, barang dan jasa, menjadi bebas keluar masuk suatu negara tanpa hambatan. Inilah yang disebut globaliasi ekonomi sekarang ini, yang secara filosofis mengacu pada faham individual, liberal, kapitalis, dan yang mengedapankan nilai-nilai kebebasan dan keadilan individual.

${ }^{5}$ Ibid., hlm. 177 
Deregulasi yang dilakukan negara-negara berkembang untuk menyurutkan peran pemerintah ini, umumnya dilakukan oleh negara-negara berkembang yang memiliki tingkat ketergantungan yang tinggi terhadap dana pinjaman dari IMF dan Bank Dunia baik untuk menutup defisit neraca pembayaran, maupun untuk membiayai pembangunan infrastruktur. Surutnya campur tangan pemerintah ini, telah mengakibatkan banyak industri di negara-negara berkembang yang mengalami kebangkrutan, karena kalah dalam persaingan pasar bebas. Keadaan ini menyebabkan banyak pemutusan hubungan kerja (PHK) dan meningkatnya angka pengangguran. Akibat selanjutnya, selain menurunnya pertumbuhan ekonomi sekaligus meningkatnya angka kemiskinan.

Sebuah laporan kritis menyimpulkan bahwa negara-negara yang menerapkan program penyesuaian struktural dengan sangat ketat, mengalami kinerja ekonomi yang sangat mengerikan; dengan peningkatan tahunan minus 0,53\%. Di sisi lain, negara-negara yang menerapkan program penyesuaian struktural yang lebih longgar mengalami pertumbuhan sebesar 2\% (dua persen), tetapi yang mengejutkan ialah negara-negara yang tidak menjalankan program-program penyesuaian struktural justeru mengalami pertumbuhan sebesar 3,5\% per tahun. ${ }^{6} \mathrm{ILO}$ memperkirakan bahwa presentase penduduk dunia yang berada di bawah garis kemiskinan meningkat dari 53,5\% di tahun 1985, menjadi 54\% di tahun 1990 di sub-Sahara Afrika, dari 23\% menjadi 27,8\% di Amerika Latin, dan menurun dari 61,1\% menjadi 59\% di Asia Selatan, dan dari 15,7\% menjadi 14,7\% di Asia Tenggara dan Asia Timur. ${ }^{7}$

Dalam laporan UNDP tahun 2001, proporsi kemiskinan dunia meningkat dengan tajam. Antara tahun 1996 dan 1999, proporsi orang hidup di bawah garis kemiskinan bertambah dari 18 persen menjadi 24 persen dari jumlah penduduk dunia. Kondisi kemiskinan menjadi semakin parah karena pendapatan kaum miskin secara keseluruhan menurun jauh di bawah garis kemiskinan. Di Indonesia, secara keseluruhan total jumlah penduduk miskin pada tahun 2000 mencapai 46,7 juta orang; naik dua kali lipat dari tahun 1995, yakni sebesar 27 juta orang.

Krisis ekonomi 1997 juga telah mendorong terjadinya pemutusan hubungan kerja besar-besaran di Indonesia. Sebelum krisis berlangsung, ketika pertumbuhan

${ }^{6}$ Laporan ini disusun oleh UNECA, 1989, seperti dikutif Abrahansen, 2000, Disciplining Democracy : Development Discourse and Good Governance in Africa, New York, Zed Books, dan dikutif kembali oleh Budi Winarno, Globalisasi dan Krisis Demokrasi, MedPress, Yogyakarta, 2007, hlm 72.

${ }^{7}$ Manuel Casel, The Rise of The Fourth World, dalam David Held and Anthony McGrew (Eds), The Global Transformations Reader : An Instroduction to Globalization Debate, Polity Press, Cambridge, 2000, seperti dikutip Ibid., hlm.73-74 
ekonomi masih berkisar angka 7\%, angka pengangguran terbuka mencapai 7\%, sedangkan angka pengangguran terbuka terdidik mencapai angka 18,6\%. Setelah terjadinya krisis, angka tersebut meningkat menjadi sekitar 17,1\% atau sekitar 15,4 juta orang. ${ }^{8}$

Antara tahun 1997 dan 1998 inflansi di Indonesia meningkat dari 6\% menjadi $78 \%$, sementara upah riil turun menjadi hanya sekitar sepertiga dari nilai sebelumnya. Daya beli masyarakat menurun karena ketidaksesuaian antara pendapatan dan pengeluaran, akibatnya semakin tinggi harga barang-barang kebutuhan pokok, maka semakin besar pula jumlah penduduk yang menjadi miskin. ${ }^{9}$

Pada tingkat global, Hirts dan Thompson ${ }^{10}$ menunjukkan bahwa sebagian besar arus investasi hanya mengalir di tiga wilayah (triad) pokok, yakni Jepang, Amerika Utara, dan Uni Eropa. Belakangan arus investasi tersebut menyebar ke negara-negara Asia Timur. Cina menjadi salah satu penerima investasi terbesar dunia saat ini. Data UNCTAD Programme on Transnational Corporations menyebutkan bahwa pada tahun 1990, arus investasi dari Uni Eropa ke Amerika Utara sebesar 7\% dari aliran investasi dunia, sedangkan aliran investasi dari Amerika Utara ke Uni Eropa sebesar 8,4\%. Aliran investasi dari Jepang dan Uni Eropa dan begitu sebaliknya menempati ranking tertinggi. Aliran investasi Jepang ke negara-negara Uni Eropa menunjukkan angka 45,5\%, sedangkan aliran investasi Uni Eropa ke Jepang sebesar 46,8\%. Selanjutnya, aliran investasi dari Jepang ke Amerika Utara sebesar 7,3\%, dan dari Amerika Utara ke Jepang sebesar $23,0 \%{ }^{11}$

Data di bidang perdagangan dunia, juga menunjukkan kecenderungan yang kurang lebih sama. Negara-negara maju yang tergabung dalam Triad masih memegang peran penting perdagangan dunia di tambah Cina dan negara-negara industri baru di kawasan Asia Timur, seperti Korea Selatan, Taiwan dan Singapura. Tujuan ekspor dunia antara tahun 1965-1995, yang dihitung berdasarkan total ekspor saat itu, yang berlangsung antar negara maju rata-rata mencapai 52,3\%, antara negara maju dan berkembang $35,7 \%$ dan antar negara berkembang sebesar $8 \% .{ }^{12}$

\footnotetext{
${ }^{8}$ Lihat Tadjudin Noer Effendy, "Globalisasi dan Kemiskinan di Indonesia Peluang dan Hambatan Upaya Penanggulangan Kemiskinan”, makalah pada Forum INFD Pertama, 2001, seperti dikutif oleh Ibid., hlm 75.

9 Sudradjat Djiwandono, Membangun Kembali Ekonomi Indonesia Dengan Paradidma Baru, dalam http// www.pacific.net.id/pakar/s/000627.html, seperti dikutip Ibid., hlm.76

${ }^{10}$ Paul Hirts dan Graham Thompson, Globalisasi adalah Mitos, Yayasan Obor, Jakarta, 2001, hlm. 146

${ }^{11}$ Ibid., hlm. 99

${ }^{12}$ David Held, at al., Global Transformastion, Politics, Economic and Culture, Standford University Press, 1999, hlm. 172.
} 
Data yang dikemukakan di atas, merupakan petunjuk bahwa globalisasi telah memunculkan ketidak-adilan dan memperluas kemiskainan. Globalisasi hanya semakin memajukan negara-negara maju, sedangkan negara-negara berkembang justeru menjadi semakin miskin. Kemiskinan tersebut akan berdampak buruk terhadap demokrasi.

Pengaruh yang ditimbulkan akibat memburuknya kemiskinan, terhadap demokrasi dapat dilihat dalam dua sisi. ${ }^{13}$ Pertama, meskipun pertumbuhan ekonomi tidak mempunyai kaitan langsung dengan sistem politik demokrasi, tetapi meningkatnya kesejahteraan dan semakin tingginya tingkat pendidikan sebagai akibat pembangunan ekonomi telah menjadi faktor penting dalam mendorong demokratisasi sistem politik suatu negara. ${ }^{14}$ Perlu biaya-biaya ekstra untuk menciptakan suatu kondisi yang menguntungkan bagi demokrasi; seperti akses informasi yang murah dan ketersediaan pendidikan yang berkualitas tetapi terjangkau. Ini tidak berarti bahwa dalam suatu masyarakat dengan tingkat kesejahteraan minimal tidak dapat tumbuh demokrasi, tetapi dalam kondisi kearah demokrasi akan jauh lebih baik dalam suatu masyarakat dimana tingkat kesejahteraan di atas rata-rata, kemudahan dalam akses pelayanan kesehatan, dan pendidikan.

Kedua, kerentanan masyarakat dalam hal kesejahteraan terutama menyangkut pemenuhan hak-hak dasar mereka yang menyangkut sandang, pangan, dan papan, akan cenderung memberi ruang bagi munculnya instabilitas yang mengundang negara melakukan tindakan-tindakan represif. Ini akan menciptakan suatu bentuk otoritarianisme baru yang akan membuat impian ke arah demokrasi menjadi semakin jauh. Dengan demikian, gerakan ke arah demokratisasi tidak lagi terbatas pada institusi-institusi politik demokratis dan penyadaran akan hak-hak politik warga negara, tetapi juga melibatkan program pengentasan kemiskinan yang lebih luas dengan cara menciptakan sistem-sistem pengaturan ekonomi yang lebih bisa menciptakan kemakmuran dan keadilan bagi sebagian besar masyarakat sesuai dengan prinsip demokrasi, dimana yang mayoritas yang akan mengelola.

George Soros dalam The Crisis of Global Capitalism (1998), menjelaskan bahwa ada suatu anggapan yang keliru bahwa demokrasi dan kapitalisme berjalan seiringan. Dalam realitas, hubungan antara demokrasi dengan kapitalisme tersebut sangat

${ }^{13}$ Lihat Budi Winarno, Loc. Cit.

${ }^{14}$ Shamsul M. Haque, "Governance and Bureaucracy in Singapore, Contemporary Reform and Implications", Internastional Political Science Review, Vol. 25 No. 2 Tahun 2004. 
kompleks. Menurutnya, kapitalisme membutuhkan demokrasi sebagai kekuatan pengimbang, karena sistem kapitalisme tidak memiliki kecenderungan untuk mencapai keseimbangan. Para pemilik modal selalu berusaha memaksimumkan keuntungan mereka, dan apabila hal itu dibiarkan lepas tanpa kendali, tentulah mereka akan berupaya untuk mengakumulasikan modal sampai pada suatu tingkat ketidak seimbangan. Pandangan ini, mengisyaratkan bahwa demokrasi seharusnya berfungsi untuk mengendalikan sistem kapitalisme. Artinya negara dan hukum harus memainkan peran sebagai pengendali dalam perekonomian global. ${ }^{15}$

Persoalannya adalah demokrasi di banyak negara sudah tidak lagi dapat berperan dalam mengendalikan sistem kapitalisme. Banyak produk legislasi dan kebijakan pemerintah yang lebih memihak pada kepentingan pemilik modal. Karena itu hukum positif yang ada sulit untuk dapat melakukan pengendalian kiprah kapitalisme global. Situasi yang demikian tentu akan mengakibatkan semakin memburuknya keadilan dan tingkat kesejahteraan rakyat banyak.

Penjelasan ini sekaligus menunjukkan bahwa neoliberalisme yang berada dibalik globalisasi ekonomi, berdampak menimbulkan krisis demokrasi di negara-negara berkembang dan pada gilirannya juga berdampak pada munculnya krisis di bidang hukum. Hukum hanya akan menjadi alat untuk memenuhi kepentingan kaum elit. Dalam situasi hukum yang elitis, penerapan hukum menurut tradisi berpikir legalpositivism, akan mengakibatkan hukum hanya mengabdi kepada kepentingan elit. Karena itu, apabila hukum ingin diabdikan pada keadilan dan kesejahteraan rakyat banyak, hal itu hanya mungkin diwujudkan, apabila penerapannya dilakukan dengan cara-cara yang progresif.

\section{Penerapan Konsep Hukum Progresif dalam Penegakan Hukum}

Dalam tradisi pemikiran legal-positivism, yang banyak dianut dalam negara demokrasi sekarang ini, hukum dikonsepsikan sebagai produk legislasi. Hukum adalah peraturan perundang-undangan yang dihasilkan melalui proses legislasi nasional. Hukum berlaku, semata-mata karena telah ditetapkan dalam bentuk peraturan perundang-undangan, tanpa melihat apakah isinya adil atau tidak adil. Dalam sistem ini, pelaku hukum (birokrasi dan hakim), sesuai dengan doktrin dalam analytical jurisprudence, hanya bertugas sebagai corong undang-undang.

\footnotetext{
${ }^{15}$ Lihat Deliarnov, Loc.Cit.
} 
Penggunaan pemikiran legal-positivism, dalam situasi hukum perundangundangan yang elitis, akan menyebabkan kesenjangan (ketidakadilan) ekonomi dan kemiskinan (ketidaksejahteraan) rakyat akan semakin meluas, sebab kemacetan demokrasi yang terjadi dibawah tekanan neoliberalisme, akan menyebabkan hukum yang dihasilkan dari proses legislasi akan cenderung berpihak pada kepentingan elit dan mengabaikan keadilan dan kesejahteraan rakyat banyak. Karena itu, untuk pemulihannya diperlukan upaya-upaya yang inovatif guna menemukan konsep hukum yang lebih berpihak kepada keadilan dan ksejahteraan rakyat.

Menurut Satjipto Rahardjo, hukum seharusnya bertugas melayani manusia, bukan sebaliknya. Mutu hukum ditentukan oleh kemampuannya untuk mengabdi pada kesejahteraan manusia. Inilah hukum progresif, yang menganut ideologi hukum yang pro-keadilan dan hukum yang pro-rakyat. Hukum progresif ini, ditawarkan untuk mengatasi krisis di era global sekarang ini. Dedikasi para pelaku hukum mendapat tempat yang utama untuk melakukan pemulihan. Para pelaku hukum, harus memiliki empati dan kepedulian pada penderitaan yang dialami rakyat dan bangsa ini. Kepentingan rakyat (kesejahteraan dan kebahagian), harus menjadi titik orientasi dan tujuan akhir penyelenggaraan hukum.

Proses perubahan tidak lagi berpusat pada peraturan, tapi pada kreativitas pelaku hukum dalam mengaktualisasi hukum dalam ruang dan waktu yang tepat. Para pelaku hukum, dapat melakukan perubahan yang kreatif terhadap peraturan yang ada tanpa harus menunggu perubahan peraturan (changing the law). Peraturan yang buruk, tidak harus menjadi penghadang bagi para pelaku hukum untuk menghadirkan keadilan bagi rakyat dan pencari keadilan, karena mereka dapat melakukan interpretasi secara baru terhadap suatu peraturan.

Interessenjurisprudenz, tegas-tegas menolak pertimbangan yuridis yang legalistik, yang dilakukan secara pasang-jarak dan in abstracto. Ia tidak memulai pemeriksaan dari bangunan peraturan secara hitam-putih, melainkan dari konteks dan kasus khusus di luar narasi tekstual aturan itu sendiri. Sebabnya adalah karena keadilan tidak bisa secara langsung ditemukan melalui proses logis-formal. Keadilan justeru diperoleh melalui intuisi. Karena itu, argumen logis-formal "dicari" sesudah keadilan ditentukan untuk membingkai secara yuridis-formal keputusan yang diyakini adil tersebut. ${ }^{16}$

${ }^{16}$ Lihat Satjipto Rahardjo, "Konsep dan Karakter Hukum Progresif”, Makalah Seminar Nasional I Hukum Progresif, Kerjasama Fakultas Hukum Undip, Program Doktor Ilmu Hukum Undip dan Fakultas Hukum Universitas Trisakti, Semarang, Desember, 2007. 
Dalam konsep hukum yang proresif, hukum tidak mengabdi pada dirinya sendiri, melainkan untuk tujuan yang berada di luar dirinya. ${ }^{17}$ Ini berbeda dengan tradisi analytical jurisprudence yang cenderung menepis dunia luar dirinya; seperti manusia, masyarakat dan kesejahteraannya. ${ }^{18}$ Dengan demkian, hukum harus bersifat responsif. Regulasi hukum akan selalu dikaitkan dengan tujuan-tujuan sosial yang melampaui narasi tekstual aturan.

Hukum progresif, memiliki logika yang mirip dengan Legal Realism, melihat dan menilai hukum dari tujuan-tujuan sosial yang ingin dicapainya serta akibatakibat yang timbul dari bekerjanya hukum itu, yang karenanya dari sudut pandang etis, dapat disebut etika teleologis. Cara berpikir teleologis ini, bukan tidak memperhatikan hukum. Aturan penting, tetapi itu bukan ukuran terakhir yang lebih diutamakan adalah tujuan dan akibat. Sebab itu, pertanyaan sentral dalam etika teleologis, adalah apakah suatu tindakan itu bertolak dari tujuan yang baik, dan apakah tindakan yang tujuannya baik itu, juga berakibat baik.

Dalam pandangan hukum progresif, pelaku hukum harus memiliki kepekaan pada persoalan-persoalan krusial dalam hubungan-hubungan manusia, termasuk keterbelengguan manusia dalam struktur-struktur yang menindas; baik politik, ekonomi, maupun sosial budaya. Dalam konteks ini, hukum progresif harus tampil sebagai institusi yang emansipatoris (membebaskan).

Hukum progresif yang menghendaki pembebasan dari tradisi keterbelengguan, memiliki kemiripan dengan pemikiran Roscoe Pound tentang hukum sebagai alat rekayasa sosial (social engineering). Usaha social engineering, dianggap sebagai kewajiban untuk menemukan cara-cara yang paling baik bagi memajukan atau mengarahkan masyarakat. ${ }^{19}$ Bukti monumental tentang penggunaan hukum sebagai alat perubahan sosial, terjadi di Amerika Serikat pada 1954. Keputusan Mahkamah Agung Amerika untuk mengubah perilaku orang kulit putih Amerika, yang sebelumnya menaruh sikap prasangka pada orang-orang negro. Untuk menghilangkan sikap tersebut, Mahkamah Agung melalui putusannya, bahwa pemisahan ras di sekolah-sekolah negeri, bertentangan dengan konstitusi Amerika.

\footnotetext{
${ }^{17}$ Ibid.

${ }^{18}$ Ibid.

${ }^{19}$ Satjipto Rahardjo, Hukum dan Perubahan Sosial: suatu Tinjauan Teoritis Serta Pengalaman-Pengalaman di Indonesia, Alumni, Bandung, 1983, hlm. 16
} 
Edwin M. Schur, melihat putusan tersebut sebagai upaya pengangkatan suatu moralitas ke dalam bentuk perundang-undangan Amerika. ${ }^{20}$

Hukum progresif lebih mengutamakan tujuan dan konteks dari pada teks aturan, maka diskresi mempunyai tempat yang penting dalam penyelenggaraan hukum. Thomas Aaron merumuskan diskresi sebagai : ...power authority conferred by law to action on the basic of judgement or conscience, and it use is more on idea of moral than law" ${ }^{21}$ Dalam konteks diskresi, para penyelenggara hukum dituntut untuk memilih dengan bijaksana bagaimana ia harus bertindak. Otoritas yang ada pada mereka berdasarkan aturan-aturan resmi, dipakai sebagai dasar untuk menempuh cara yang bijaksana dalam menghampiri kenyataan tugasnya berdasarkan pendekatan moral dari pada ketentuan-ketentuan formal. Weston menyatakan "decicion making has been termed the selection of the best, the most practical or satisfactory course of action." 22

Dalam penyelenggaraan hukum diskresi merupakan faktor wewenang hukum yang dijalankan secara bertanggungjawab dengan mengutamakan pertimbangan moral dari pada peraturan abstrak. Diskresi yang dilakukan seorang penyelenggara hukum, semata-mata atas dasar pertimbangan tentang kegunaan dan kefungsian tindakan itu dalam mencapai tujuan yang lebih besar demi menjaga kewibawaan hukum itu sendiri. Dalam kata-kata Louis A Redelet, ditegaskan bahwa "Law is not an end in itself. Propersly understood, it is a means ti higher end human affair, much as good order, justice." 23

Diskresi dilakukan karena dirasakan sarana hukum kurang efektif dan terbatas sifatnya dalam mencapai tujuan hukum dan sosial. ${ }^{24}$ Menurut Doorn, tujuan-tujuan yang dirumuskan dalam ketentuan hukum, seringkali begitu kabur, sehingga memberi kesempatan kepada pelaksananya untuk menambahkan/menafsirkan sendiri dalam konteks situasi yang ia hadapi. ${ }^{25}$ Tujuan-tujuan seperti keadilan, kepastian, keserasian, misalnya, adalah terlalu umum sehingga para pelaksana berpeluang mengembangkan penafsiran mengenai sekalian tujuan itu. ${ }^{26}$ Kehadiran pelaku hukum yang arif, visioner, dan kreatif, mutlak diperlukan untuk memandu pemaknaan yang kreatif terhadap aturan-aturan yang demikian itu.

\footnotetext{
${ }^{20}$ Ibid.

${ }^{21}$ Thomas Aaron, The Control of Police Discretion, Springfield, Charles D. Thomas, 1960, hlm. 134

${ }^{22}$ Paul M. Weston, Suvervision in the Administration of Justice Police Corrections Cours, Springfield, Charles D. Thomas, 1965, hlm. 97

${ }^{23}$ M. Fal, Penjaringan Perkara Pidana oleh Polisi (Diskeresi Kepolisian), Pradnya Paramita, Jakarta, 1991.

${ }^{24}$ Satjipto Rahardjo, Masalah Penegakan Hukum, Sinar Baru, Bandung, 1983, hlm. 79

${ }^{25}$ Ibid.

${ }^{26}$ Ibid.
} 
Penerapan hukum progresif, yang pada dasarnya terarah kepada para pelaku hukum ini, diharapkan akan dapat mengarahkan hukum yang dihasilkan oleh proses legislasi, yang cenderung elitis, untuk mengarah pada kepentingan keadilan dan kesejahteraan rakyat banyak.

Pintu masuk bagi penerapan hukum progresif dalam praktik pengadilan di Indoensia, secara formal telah diberikan oleh UU Kekuasaan Kehakiman yang menegaskan bahwa kekuasaan kehakiman bertugas untuk menegakkan hukum dan keadilan. Dalam rangka itu, hakim diwajibkan untuk menggali nilai-nilai hukum dan keadilan yang hidup dalam masyarakat. ${ }^{27}$ Ini berarti bahwa hakim tidak sekedar bertugas menerapkan peraturan apa adanya, tetapi bagaimana penerapan itu dapat mewujudkan keadilan. Di sini kreativitas hakim menjadi sangat menentukan.

Hasil penelitian terhadap sengketa dalam pelaksanaan kontrak, ${ }^{28}$ menunjukkan ${ }^{29}$ bahwa pengadilan di Indonesia pada awalnya sangat mengedepankan asas facta sunt servanda dari pada asas iktikad baik. Mengedepankan asas facta sunt servanda, berarti mengedepankan isi perjanjian sesuai dengan apa yang secara formal sudah disepakati oleh para pihak secara sah, dan itulah yang oleh pengadilan diberlakukan sebagai undang-undang bagi para pihak. Ini merupakan gambaran dari cara berpikir yang legal-positivism, yang hanya memaknai aturan (dalam hal ini perjanjian) secara formaltektual, yang mengabaikan keadilan. Dalam penelitian ini juga ditunjukkan ${ }^{30}$ bahwa belakangan, sikap pengadilan Indonesia ternyata bergeser ke arah yang lebih mengedepankan iktikad baik. Mengedepankan iktikad baik, berarti pengadilan tidak lagi terbelenggu untuk mengikuti teks perjanjian, melainkan lebih melihat pada nilainilai kepatutan dan keadilan yang hidup dalam masyarakat. Ini merupakan gambaran bahwa dalam memutus sengketa pelaksanaan kontrak, pengadilan Indonesia, telah bergeser menjadi progresif.

Dalam penelitian lain, terkait dengan pemaknaan tindakan melawan hukum dalam Tindak Pidana Korupsi, ${ }^{31}$ masih banyak hakim yang terkungkung dengan

${ }^{27}$ Pasal 28 UU No.4 Tahun 2004 tentang Kekuasaan Kehakiman.

${ }^{28}$ Ridwan Khairandy, "Makna, Tolok Ukur, Pemaknaan dan Sikap Pengadilan di Indonesia Terhadap Iktikad Baik dalam Pelaksanaan Kontrak", Jurnal Hukum, Fakultas Hukum UII, No. Edisi Khusus, Vol. 16 Oktober 2009.

${ }^{29}$ Diantaranya Putusan MA No.289 K/Sip/1972 dalam perkara Ida Ayu Surjani v I. Nyoman Sudirdja, dan Putusan MA No. 791 K/Sip/1972 dalam perkara Tjan Thiam Songa Tjia Khun Tjai.

${ }^{30}$ Diantaranya, Putusan MA No.1253 K/Sip/1973 dalam perkara antara Zainul Abidin v A.M. Muhammad Zainuddin, Putusan MA No.3431 K/Pdt 1985 dalam perkara Sri Setyaningsih v Ny. Boesono dan R Boesono, dan Putusan MA No.1531 K/Pdt/1997 dalam perkara Hetty Esther v Anak Agung Sagung Partini.

${ }^{31}$ Seperti yang dilaporkan oleh M. Syamsudin, "Kecenderungan Paradigma Berpikir Hakim Dalam Memutus Perkara Korupsi”, Jurnal Media Hukum Fakultas Hukum UMY, Vol. 15 No.2 Desember 2008 
cara berpikir yang legal-positivism. Tindakan melawan hukum hanya dimaknai terbatas pada rumusan teks yang sudah ada dalam peraturan perundang-undangan, tanpa memperdulikan nilai-nilai kepatutan dan keadilan. Akibatnya, sekalipun tindakan terdakwa bertentangan dengan nilai-nilai kepatutan, tidak sedikit terdakwa yang diputus bebas oleh Pengadilan, karena dianggap tidak berbukti telah melakukan perbuatan yang melawan perundang-undangan. ${ }^{32}$

Dalam penelitian ini juga ditunjukkan adanya hakim yang berpikir progresif, yang memaknai tindakan melawan hukum sebagai tindakan yang melanggar kepatutan. Nilai kepatutan tersebut tidak terdapat di dalam teks, tetapi digali dalam masyarakat, sehingga dalam putusannya, terdakwa tidak bisa lepas dari hukuman pidana. ${ }^{33}$ Sekalipun sudah terdapat hakim yang berpikir progresif, tetapi penelitian ini menyimpulkan bahwa cara berpikir legal-positivism masih menjadi mainstream di kalangan hakim di Pengadilan.

Berdasarkan hasil penelitian yang dikemukakan di atas, tradisi berpikir hakim di Pengadilan, sudah mulai diwarnai oleh cara berpikir yang progresif. Tradisi berpikir yang progresif ini perlu terus didorong, agar benar-benar menjadi budaya hukum dikalangan hakim. Apabila para hakim, sudah tidak lagi terbelenggu dengan tradisi berpikir legal-positivism, maka tujuan hukum untuk mewujudkan keadilan dan kesejahteraan rakyat, akan menjadi lebih memungkinkan, sekalipun hukum perundang-undangan yang dihasilkan dalam proses legislasi cenderung elitis.

\section{Penutup}

Berdasarkan uraian yang telah dikemukakan dalam bagian pembahasan di atas, dapat disimpulkan : Pertama, globalisasi telah mengakibatkan terjadinya kesenjangan (ketidakadilan) ekonomi dan meluasnya kemiskinan. Kemiskinan akan berdampak buruk terhadap demokrasi. Demokrasi yang buruk, cenderung menghasilkan produk

32 Putusan yang menunjukkan masih diikutinya tradisi legal-postivism, terlihat dintaranya dalam Putusan Pengadilan Negeri Kupang No.176/PD/B/2006/PN.KPG dalam Kasus Tipikor Ruben Funai (mantan Ketua DPRD Kabupaten Kupang Periode 1999-2004), Putusan Pengadilan Negeri Denpasar No. 04.226/PD/B/2006/PN.Dps, dalam Kasus Tipikor Ida Bagus Putu Wesrawa (ketua DPRD Provinsi Bali), Putusan Pengadilan Negeri Denpasar No.630/PD/B/2000/PN.DPS dalam Kasus Tipikor Ida Bagus Oka (mantan Gubernur Bali).

${ }_{33}$ Putusan Progresif, diantaranya terlihat dalam Putusan Pengadilan Negeri Yogyakarta No.26/Pd.B/2006/ PN.YK, dalam perkara Cinde Laras Yulianto dan Arief Eddy Subianto, Putusan Pengadilan Negeri Banjarmasin No. 704/Pd/B/2005/PN.BJM dalam perkara Midfai Yabani (Walikota Banjarmasin), Putusan Pengadilan Negeri Jakarta Pusat No.01/Pd./B/2004/PN.JKTPST dalam perkara Ir. H. Abdullah Puteh, M.S., (Gubernur Propinsi NAD) 
hukum yang elitis, mengabaikan keadilan dan kesejahteraan rakyat banyak. Kedua, dalam situasi produk legislasi yang elitis, maka penerapan hukum yang didasarkan pada tradisi legal-positivism, akan semakin memperluas ketidakadilan dan kemiskinan. Karena, itu, di tengah situasi produk legislasi yang elitis, penerapan hukum secara progresif, merupakan cara alternatif yang lebih memungkinkan untuk mewujudkan keadilan dan kesejahteraan rakyat. Kehadiran para pelaku hukum yang visioner, peka terhadap nilai-nilai moral dan keadilan, jujur, serta amanah akan dapat menghasilkan putusan-putusan hukum yang lebih berpihak kepada keadilan dan kesejahteraan rakyat banyak, sekalipun produk hukum yang dihasilkan oleh proses demokrasi cenderung elitis. Ketiga, praktik pengadilan di Indonesia, menunjukkan mulai berkembangnya cara-cara penerapan hukum yang progresif, namun tradisi legal-positivism masih menjadi mainstream para hakim.

\section{Daftar Pustaka}

Aaron, Thomas, The Control of Police Discretion, Springfield Charles D. Thomas, 1960.

Casel, Manuel, The Rise of The Fourth World, dalam David Held and Anthony McGrew (Eds), The Global Transformations Reader : An Instroduction to Globalization Debate, Cambridge Polity Press, 2000

Djiwandono, Sudradjat, 2000, Membangun Kembali Ekonomi Indonesia Dengan Paradidma Baru, (Cambridge, 27 Juni 2000) dalam http/ / www.pacific.net.id/pakar/ s/000627.html,

Deliarnov, Ekonomi Politik, Penerbit Erlangga, Jakarta, 2006.

Fal, M., Penjaringan Perkara Pidana oleh Polisi (Diskresi Kepolisian), Pradnya Paramita, Jakarta, 1991.

Held, David, at al., Global Transformastion, Politics, Economic and Culture, Standford University Press, 1999.

Hirts, Paul dan Thompson, Graham, Globalisasi adalah Mitos, Yayasan Obor, Jakarta, 2001.

Khairandy, Ridwan, Makna, Tolok Ukur, Pemaknaan dan Sikap Pengadilan di Indonesia Terhadap Iktikad Baik Dalam Pelaksanaan Kontrak, Jurnal Hukum, Fakultas Hukum UII, Edisi Khusus, 16 Oktober 2009.

M. Haque, Shamsul, Governance and Bureaucracy in Singapore, Contemporary Reform and Implications, Internastional Political Science Review, Vol. 25 No. 2 Tahun 2004.

Noer Effendy, Tadjudin, Globalisasi dan Kemiskinan di Indonesia Peluang dan Hambatan Upaya Penanggulangan Kemiskinan, makalah pada Forum INFD Pertama, 2001. 
Ohmae, Kenich, Hancurnya Negara Bangsa, Bangkitya Negara Kawasan dan Geliat Ekonomi Regional di Dunia Tak Terbatas, Qalam, Yogyakarta, 2002.

Rahardjo, Satjipto, Hukum dan Perubahan Sosial : suatu Tinjauan Teoritis Serta Pengalaman-Pengalaman di Indonesia, Alumni, Bandung, 1983.

, Makalah, Konsep dan Karakter Hukum Progresif, Fakultas Hukum Undip bekerja sama dengan Program Doktor Ilmu Hukum Undip, Semarang, Desember 2007.

Robinson, Wiliam I., Neoliberalisme : Elit Global dan Transisi Guatemala : sebuah Analisis Kritis Makrostruktural, dalam Wiliam I . Robinson, (Ed) Hantu Neoliberalisme, C-Books, Jakarta, 2003

Scholte, Jan Aart, Globalization : A Critical Introduction, New York; St. Martin Press, 2000.

Syamsudin, M., Kecenderungan Paradigma Berpikir Hakim Dalam Memutus Perkara Korupsi, Jurnal Media Hukum Fakultas Hukum UMY, Vol. 15 No.2 Desember 2008.

Weston, Paul M., Suvervision in the Administration of Justice Police Corrections Cours, Springfield : Charles D. Thomas, 1965.

Winarno, Budi, Globalisasi dan Krisis Demokrasi, MedPress, Yogyakarta, 2007. 